\title{
PENGOLAHAN DATA PENERIMA KARTU INDONESIA SEHAT MENGGUNAKAN TRANSACTION PROCESSING SYSTEM
}

\author{
Dede Wira Trise Putra'),Syaiful Rahman ${ }^{2)}$ \\ Jurusan Teknik Informatika \\ Fakultas Teknik \\ Institut Teknologi Padang \\ dedewtp339@yahoo.com
}

\begin{abstract}
Healthy Indonesia Card (KIS) is a government aid whose recipient data is submitted to each region for processing. The data processing of the Healthy Indonesia Card (KIS) uses the bookkeeping method. The problems and obstacles faced are the occurrence of file stacking, file damage, difficulties in finding data and the occurrence of data duplication in the data input process. These problems lead to errors in the use of data by interested parties. Based on the existing problems, a Transaction Processing System (TPS) was designed to facilitate data processing and minimize errors and errors. The designed Transaction Processing System (TPS) is a web-based information system. The use of this system can make data stored properly and regularly. And if there is an addition and deletion of data can be done directly by the user concerned. Transaction Processing System for processing population data can provide convenience for users in inputting and processing data. The designed system has been built and tested based on user requirements.
\end{abstract}

Keywords: Transaction Processing System, Data Processing, Web, KIS

\section{Intisari}

Kartu Indonesia Sehat (KIS) merupakan bantuan pemerintah yang data penerimanya diserahkan kepada setiap wilayah untuk diolah. Pengolahan data Kartu Indonesia Sehat (KIS) menggunakan cara pembukuan. Permasalahan dan kendala yang dihadapi adalah terjadinya penumpukkan berkas, kerusakan berkas, kesulitan dalam pencarian data dan terjadinya duplikasi data dalam proses penginputan data. Permasalahan tersebut menyebabkan kekeliruan terhadap pemanfaatan data oleh pihak yang berkepentingan. Berdasarkan permasalahan yang ada maka dirancang sebuah Transaction Processing System (TPS) untuk mempermudah dalam pengolahan data dan meminimalisir kesalahan dan kekeliruan. Transaction Processing System (TPS) yang dirancang yakni sebuah sistem informasi berbasis web. Penggunaan sistem ini dapat membuat data tersimpan dengan baik dan teratur. Serta jika terjadi penambahan dan penghapusan data dapat dilakukan langsung oleh pengguna yang berkepentingan. Transaction Processing System untuk pengolahan data penduduk ini dapat memberikan kemudahan bagi pengguna dalam penginputan dan pengolahan data. Sistem yang dirancang telah dibangun dan diuji berdasarkan kebutuhan pengguna.

Kata Kunci :Transaction Processing System, Pengolahan Data, Web, KIS

\section{PENDAHULUAN}

Data Kartu Indonesia Sehat (KIS) merupakan data masyarakat yang akan diolah untuk penerima KIS. Tata kelola dan pengolahan data saat ini membutuhkan sebuah sistem yang dapat mengakomodir hal tersebut. Hal ini 
dikarenakan banyaknya data dan waktu yang dibutuhkan dalam mandapatkan data yang baik. Pengolahan data merupakan Pengolahan data merupakan tahapan mengolah data sesuai dengan prosedur yang telah dimasukkan lalu memproses menggunakan proses tertentu, dan menghasilkan datadalam bentuk informasi [1]. Pengolahan data oleh pihak Program Keluarga Harapan (PKH) terhadap data penerima Kartu Indonesia Sehat (KIS) saat ini masih menggunakan metode pencatatan pembukuan. Hal ini mengakibatkan terjadinya penumpukkan berkas, kerusakan berkas, kesulitan dalam pencarian data dan terjadinya duplikasi data.

Transaction Processing System(TPS) dapat dijadikan salah satu solusi dalam menyelesaikan masalah yang ditemukan. TPS merupakan sebuah sistem yang berinteraksi langsung dengan sumber data yang bertugas dalam pengolahan data transaksi yang mendukung operasional organisasi [2]. TPS adalah sistem yang menjadi pintu utama dalam pengumpulan dan mempersiapkan data untuk keperluan sistem informasi. TPS menjadi bagian penting dalam mendukung operasi pengolahan dan perekaman data laporan dari transaksi bisnis [3].

TPS berfungsi untuk mengumpulkan, menyimpan, memproses data transaksi yang disajikan dalam bentuk laporan yang dibutuhkan sesuai hasil pemrosesan. Sehingga, aplikasi yang digunakan dalam sebuah TPS dapat mendukung jalannya fungsi-fungsi secara baik dan tepat waktu [4].

\section{METODE PENELITIAN}

Metodologi yang digunakan dalam penelitian ini menggunakan model waterfall yang bersifat sistematis, berurutan dalam membangun software. Tahapan metode penelitian yang dilakukan dalam penelitian adalah sebagai berikut [5] :
1. Pengumpulan Data

Beberapa langkah yang di kerjakan dalam tahap ini yaitu:

a. Studi Pustaka

Studi pustaka merupakan tahap awal dalam pengumpulan data pada penelitian. Metode ini dilakukan dengan cara mencari sumber-sumber referensi pada buku, maupun jurnal yang dianggap penting dan mendukung.

b. Wawancara

Wawancara dilakukan kepada pihak yang terkait langsung dengan sistem yang akan dibuat.

c. Pengumpulan Data dan Informasi

Pengumpulan data dan Informasi dalam bentuk wawancara dilakukan sebagai bahan untuk identifikasi dalam melihat permasalahan yang dihadapi.

2. Tahap Analisa dan Perancangan

Tahap analisa dan perancangan ini berfungsi untuk menemukan solusi terhadap masalah yang ada dan mendiskusikan dengan pembimbing kerja praktek.

3. Tahap Implementasi dan Pengujian

Tahap ini merupakan tahap penyusunan dan pemilihan perangkat keras (hardware), perangkat lunak sistem (coding) dan pengujian (testing) yang akan memberikan hasil kelayakan sistem.

\section{HASIL DAN PEMBAHASAN}

Level pengguna pada sistem pengolahan data ini terlihat pada context diagram pada gambar 1 berikut ini :

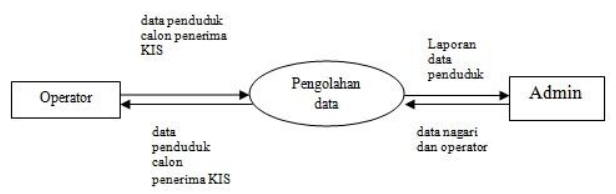




\section{Gambar 1. Context Diagram}

Sistem yang dibangun memiliki dua level pengguna yakni :

1. Operator yang bertugas memasukkan data ke dalam sistem dan mendapatkan balasan berupa data yang telah dientrikan.

2. Admin sebagai level user tertinggi yang dapat mengatur dan mengelola sistem.

Sistem yang dirancang terdiri satu database yang memiliki empat tabel yang saling berelasi untuk mengakomodir penyimpanan dan pemanggilan data.

Halaman sistem yang dirancang terdiri atas beberapa halaman yang tergambar pada struktur program di bawah ini.

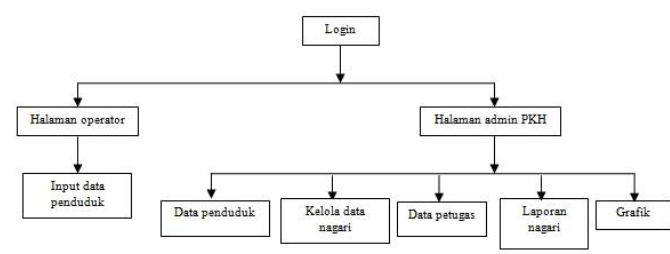

Gambar 2. Struktur Program

Halaman utama dari sistem yang dibangun adalah halaman login. Penggunaan halaman $\log$ in sebagai halaman utama dikarenakan level user yang ada memiliki level verifikasi akun dengan menginputkan username dan password.

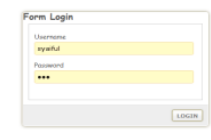

Gambar 3. Halaman Log In

Gambar 3 merupakan halaman login yang dapat langsung diakses oleh pengguna ketika mengakses sistem yang dirancang. Hak akses dikelola oleh admin, untuk menambahkan operator.

Halaman utama operator merupakan halaman yang akan digunakan oleh operator untuk melakukan tugas entry data ke dalam sistem. Pada halaman ini, operator dapat menambah data baru, melakukan perubahan dan penghapusan serta mengurut dan melakukan pencarian terhadap data yang ada.

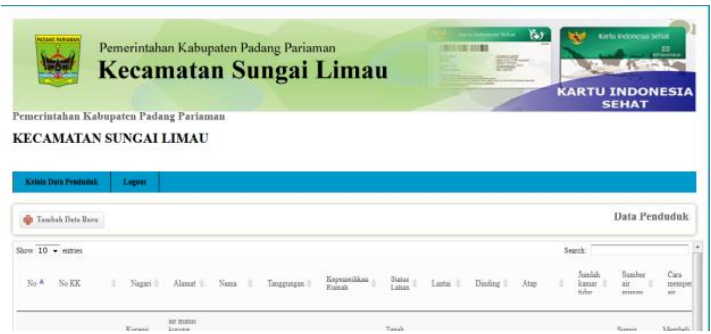

Gambar 4. Halaman Utama Operator

Penambahan data dengan cara diinput pada sistem yang dirancang menggunakan tampilan sesuai dengan jenis yang ada yakni menggunakan struktur insert dengan combo box, option button dan text box.

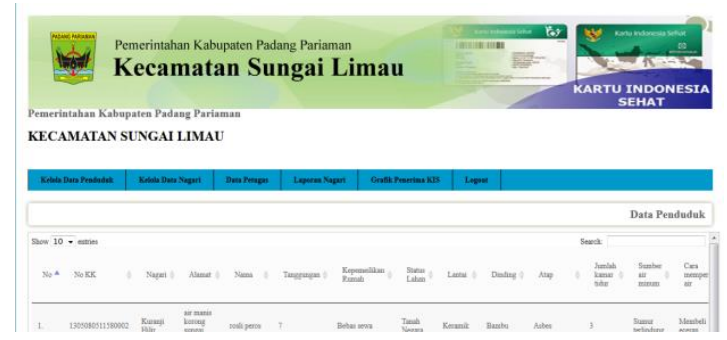

Gambar 5. Halaman Data Penduduk

Halaman data penduduk pada gambar 5 merupakan halaman yang digunakan untuk menampilkan data yang telah diinputkan oleh operator. Halaman ini dapat mengakomodir aktivitas edit dan hapus terhadap data yang telah dientrykan.

Halaman data penduduk juga dapat mengurutkan data yang telah dientrykan sesuai dengan kolom yang 
diinginkan. Serta pengguna dapat melakukan pencarian data sesuai dengan kata kunci yang diinputkan.

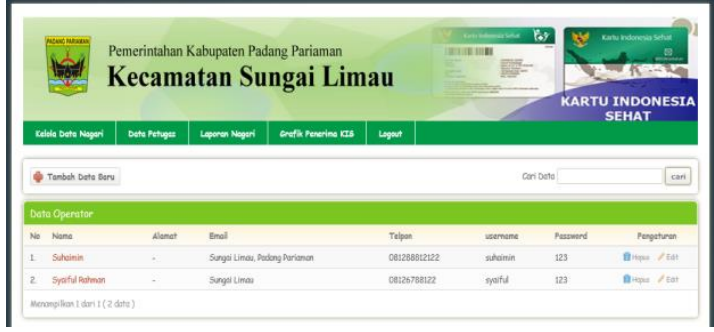

Gambar 6. Halaman Data Operator

Halaman data operator merupakan halaman yang digunakan untuk menampilkan operator yang memiliki hak akses terhadap sistem. Halaman ini merupakan halaman yang dapat diakses oleh admin atau level user tertinggi pada sistem. Admin dapat melakukan pengeditan dan penghapusan terhadap data operator. Halaman ini seperti pada gambar 6 .

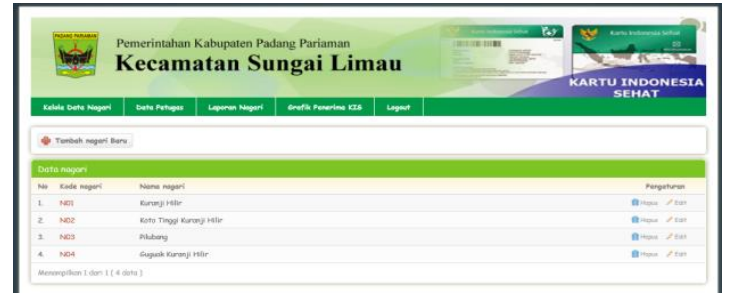

Gambar 7. Halaman Data Nagari

Gambar 7 merupakan halaman yang digunakan oleh admin untuk mengentrikan data nagari. Data dimasukkan oleh admin sehingga operator dapat mengakses data dari combo box yang telah disediakan pada halaman operator. Admin dapat melakukan penghapusan dan pengeditan terhadap data nagari. Halaman ini bertujuan agar ketika operator mengentrikan data nagari, data yang masuk memiliki isi yang sama.
Pecerinatam Kaburaten padane Prarianan

Kecamatan sons

Dats operater

-

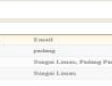

Gambar 8. Halaman Data Penduduk

Gambar 8 merupakan halaman untuk menampilkan data penduduk. Pada halaman ini terdapat menu tambah, hapus dan edit. Selain itu juga terdapat menu untuk searching.

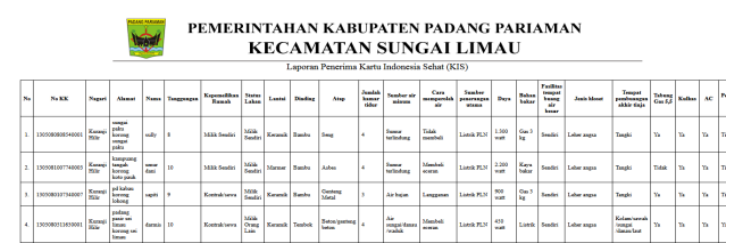

Gambar 9. Laporan Data Penduduk

Gambar 9 merupakan tampilan halaman laporan data penduduk. Pada halaman ini ditampilkan hasil rekap data pendukuk yang telah dimasukkan.

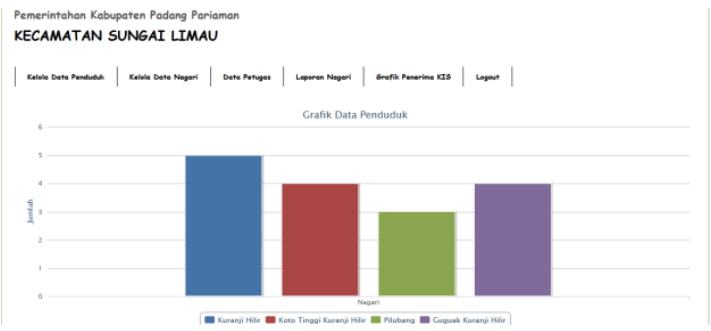

Gambar 10. Grafik Data Penduduk

Grafik pada gambar 10 merupakan data penduduk yang dikelompokkan berdasarkan data nagari.

Tabel 1. Tabel Pengujian Blackbox 
DOI : https://doi.org/10.47233/jteksis.v4i1.333

\begin{tabular}{|c|c|c|c|}
\hline Pengujian & Deskripsi & Hasil yang diharapkan & Kesimpulan \\
\hline \multirow[t]{2}{*}{ Halaman Login } & $\begin{array}{l}\text { Ketika } \\
\text { mengklik } \\
\text { tombol login }\end{array}$ & $\begin{array}{l}\text { Jika input kosong, maka akan } \\
\text { muncul pesan username dan } \\
\text { password tidak valid }\end{array}$ & Berhasil \\
\hline & & $\begin{array}{l}\text { Jika input username dan password } \\
\text { benar maka akan diarah ke halaman } \\
\text { utama aplikasi }\end{array}$ & Berhasil \\
\hline Halaman Utama & Menu & Pilihan menu/form & Berhasil \\
\hline $\begin{array}{l}\text { Menu data } \\
\text { nagari }\end{array}$ & $\begin{array}{l}\text { Klik menu } \\
\text { data nagari }\end{array}$ & $\begin{array}{l}\text { Muncul halaman tambah kelola data } \\
\text { nagari }\end{array}$ & Berhasil \\
\hline $\begin{array}{l}\text { Menu data } \\
\text { petugas }\end{array}$ & $\begin{array}{l}\text { Pilih menu } \\
\text { data operator }\end{array}$ & Muncul halaman kelola data operator & Berhasil \\
\hline $\begin{array}{l}\text { Laporan data } \\
\text { nagari }\end{array}$ & $\begin{array}{l}\text { Klik menu } \\
\text { laporan data } \\
\text { nagari }\end{array}$ & Muncul halaman cetak laporan & Berhasil \\
\hline $\begin{array}{l}\text { Menu tambah } \\
\text { data penduduk }\end{array}$ & $\begin{array}{l}\text { Klik menu } \\
\text { input data } \\
\text { penduduk }\end{array}$ & Muncul halaman input data & Berhasil \\
\hline Menu edit & $\begin{array}{l}\text { Pilih tombol } \\
\text { edit }\end{array}$ & Muncul halaman data penduduk & Berhasil \\
\hline Menu hapus & $\begin{array}{l}\text { Pilih tombol } \\
\text { hapus }\end{array}$ & $\begin{array}{l}\text { Jika klik tombo hapus, maka akan } \\
\text { muncul pesanapakah anda yakin } \\
\text { menghapus data ini }\end{array}$ & Berhasil \\
\hline Menu grafik & $\begin{array}{l}\text { Pilih tombol } \\
\text { grafik }\end{array}$ & Muncul grafik data penduduk & Berhasil \\
\hline $\begin{array}{l}\text { Menu cetak } \\
\text { laporan }\end{array}$ & $\begin{array}{l}\text { Pilih tombol } \\
\text { cetak laporan }\end{array}$ & Laporan dicetak & Berhasil \\
\hline Menu pencarian & $\begin{array}{l}\text { Pilih menu } \\
\text { pecarian }\end{array}$ & $\begin{array}{l}\text { Akan diarahkan kehalaman yang } \\
\text { dicari }\end{array}$ & Berhasil \\
\hline $\begin{array}{l}\text { Simpan data ke } \\
\text { database }\end{array}$ & Penyimpanan & $\begin{array}{l}\text { Data yang diinputkan akan tersimpan } \\
\text { didatabase }\end{array}$ & Berhasil \\
\hline Validasi no KK & Validasi & Input no kk 16 & Berhasil \\
\hline Logout & $\begin{array}{l}\text { Ketika } \\
\text { memilih } \\
\text { Logout }\end{array}$ & $\begin{array}{l}\text { Keluar dari menu aplikasi dan } \\
\text { diarahkan ke halaman login }\end{array}$ & Berhasil \\
\hline
\end{tabular}

Tabel 1 merupakan pengujian black box yang dilakukan terhadap sistem yang dirancang. Pengujian blackbox merupakan sebuah pengujian yang dapat menginformasikan sesuai atau tidaknya sistem yang dirancang dengan analisa kebutuhan sistem di awal[6]. Hasil pengujian ini adalah sistem yang dirancang berjalan sesuaid dengan tujuan. Setiap menu berjalan sesuai dengan fungsinya dan mengeluarkan output sesuai dengan tujuan setiap halaman. 


\section{SIMPULAN}

Perancangan TPS dalam pengelolaan data dapat digunakan dengan baik oleh pengguna. Berdasarkan tujuan sistem dibuat TPS yang dirancang dapat menyimpan data dan proses pemanggilan data dapat berjalan dengan baik. Sistem yang dirancang terhadap ransaksi data dapat meminimilisir kesalahan yang dilakukan oleh pengguna. Setiap halaman yang dirancang setelah pengujian dilakukan diperoleh hasil bahwa setiap halaman dapat berjalan sebagaiman mestinya.

\section{DAFTAR PUSTAKA}

[1] P. A. Y. Larissa Navia Rani, Hari Marfalino, "Sistem Informasi dan Pengolahan Data Akses VIirtual Host Bebasis Client Server dan Database MySQL," J. Teknol. dan Inf. Bisnis, vol. 1, no. 2, pp. 88-92, 2019.

[2] M. R. Ristyawan, "Pengaruh Transaction Processing System Aplikasi Android Book Keeper Accounting Terhadap Decision Support System pada UMKM di Kota Pontianak," J. Akunt. Keuang. dan Bisnis, vol. 11, no. 2, pp. 4756, 2018.

[3] T. A. Kurniawan, T. W. Wisjhnuadji, and F. Riandono, "Implementasi Transaction Processing System Berbasis Web Dan Mobile," J. Ilm. Fak. Tek., vol. 1, no. 1, pp. 43-49, 2019.

[4] R. G. Maliq, R. R. Isnanto, and I. P. Windasari, "Sistem Pemrosesan Transaksi Pada Toko Bangunan Berbasis Web Dengan PHP dan MySQL," J. Teknol. dan Sist. Komput., vol. 2, no. 2, pp. 170174, 2014.

[5] J. Teknologi et al., "Rancang Bangun Sistem Pendataan Hardware," J. Teknol. dan Inf. Bisnis, vol. 3, no. 2, pp. 412-418, 2021.

[6] B. A. Priyaungga, D. B. Aji, M. Syahroni, N. T. S. Aji, and A. Saifudin, "Pengujian Black Box pada Aplikasi Perpustakaan Menggunakan Teknik Equivalence Partitions," J. Teknol. Sist. Inf. dan Apl., vol. 3, no. 3, p. 150, 2020. 